\title{
The Impact of Customer Feedback on Organizational Health when Employee Empowerment works as a moderator: Evidence from Pakistani Fast Food Industry
}

Hafiz Muhammad Naveed (Corresponding author)

School of Finance and Economics, Jiangsu University

301 Xuefu Road, Zhenjiang 212013, Jiangsu Province, China

Tel: 86-186-5128-9309Ｅ-mail: Hafiznaveed778@ gmail.com

\section{Yao Hongxing}

School of Finance and Economics, Jiangsu University

301 Xuefu Road, Zhenjiang 212013, Jiangsu Province, China

Tel: 86-8879-2098Ｅ-mail: hxyao@ujs.edu.cn

Muhammad Akhtar

School of Finance and Economics, Jiangsu University

301 Xuefu Road, Zhenjiang 212013, Jiangsu Province, China

Tel: 86-186-5283-1185_E-mail: muhammadakhtar22@outlook.com

Muhammad Usman Anwer

School of Computer Engineering, Aptech Computer Education Institute 415-E Johar Town Lahore 54782, Pakistan

Tel: 92-323-664-8402Ｅ-mail: uanwer741@gmail.com

\section{David Alemzero}

School of Finance and Economics, Jiangsu University 301 Xuefu Road, Zhenjiang 212013, Jiangsu Province, China

Tel: 86-186-5347-3523Ｅ-mail: davidajene1985@gmail.com 
Received: June 18, 2020 Accepted: July 9, 2020 Published: July 19, 2020

doi:10.5296/ber.v10i3.17372

URL: https://doi.org/10.5296/ber.v10i3.17372

\begin{abstract}
Organizational health is a modern and wide-ranging phenomenon that essential to endure long term achievements of an organization. The main objective of the current research study, to examine the effects of customer feedback on organizational health when employee empowerment works as a moderator. For this significant purpose, data was collected by respondents via using five Point Likert-scale techniques. The current research study has taken 750 total sample size from population to do expose hide phenomenon. We have used Factor Wise Reliability approach to test questions reliability; Descriptive Statistics verified whether data normalized or not; Pearson correlation to check the variables association-ship; Multiple linear regression technique to quantify per-point and overall fraction between dependent and independent variables; and finally linear regression moderation equation also conclude in methodological part for examines the moderation effect. The result indicates that Customer Feedback and organizational health both have been positively associated with each other. Besides, employees empowerment makes more strengthen the relationship of customer feedback and organizational health. In the light of outcome of current study, the manager should be aware about employees empowerment and customer feedback that are an order to sustain old customers and attract new customers for the Fast Food Industry. This research study has released new and different path for empirical investigation among organizational health, customer feedback and employees empowerment.
\end{abstract}

Keywords: Organizational health, Customer feedback, Employee empowerment, Fast food industry

\title{
1. Introduction
}

Organizational health is a modern and wide-ranging phenomenon that obligatory to endure long term achievements of an organization. The $\mathrm{OH}$ phenomenon has comprised on goal-focused of organization, optimal utilization of resources, best communication capability, innovativeness efforts and problem-solving skills as well as competitiveness, profitability ratio, vivacity and firms size (Cartwright \& Cooper, 2014; Quick, Macik-Frey, \& Cooper, 2007; Sabir, Irfan, Akhtar, Pervez, \& ur Rehman, 2014; Tetrick, 2002). We acknowledged that it isnot a complete description of $\mathrm{OH}$. However, here we are strained to illuminate the interconnection between $\mathrm{OH}$ and employee's performance (Jones, Mason, \& Benefield) by keeping an eye on previous literature (MacIntosh, MacLean, \& Burns, 2007). Grandey and Diamond (2010), have addressed that stimulation, manners and employee's performance directly affected customers attractions. Moreover, they have emphasized inspiration and employee's health both interconnected with customer's reaction (Grandey, 2000; Grandey \& Diamond, 2010; Grant, 2007). In the previous study has deliberated that organizational employees could be effect more or less from positive CFB as well as negative CFB (Maslach, 1978). Besides, it also depends on them (client) whether they can appreciate employees with 
reward or hurt with their own ridicules comments. The essential purpose of the current study, to explore the crucial missing facts regarding organizational health $(\mathrm{OH})$ \& customer feedback (CFB), especially in the context of its dimensions. In addition, EE is also part of this study as a moderator power between $\mathrm{CFB}$ and $\mathrm{OH}$.

In the modern era, many organizations have an additional focus on the lunched appropriate management system for CFB (Markey, Reichheld, \& Dullweber, 2009). (Morgan, Anderson, \& Mittal, 2005; Wirtz, Tambyah, \& Mattila, 2010) have emphasized that the upper level of management obtained information from a lower level of management about CFB and hurried action on it. Moreover, CFB is the best tool for an organization evaluation and any organizational-establishment construct plans under its tool (Wirtz et al., 2010). Besides, past studies have explored that $\mathrm{EE}$ and $\mathrm{OH}$ both are highly positive associated with each other(Newell, 1995; Wilson, Dejoy, Vandenberg, Richardson, \& Mcgrath, 2004).

According to previous literature, we slightly differ from others studies as following; first one we measure $\mathrm{OH}$ with different dimensionality function like as Surrender control, create buy-in, source new ideas, get the employee vote, \& create a team; the second one, we are estimating that how EE as moderator makes more strengthen the relationship of $\mathrm{CFB}$ and $\mathrm{OH}$; the third one, we are evaluating CFB with different dimensionality as like CS, PSQ, CR and CL. Van Jaarsveld, Walker, and Skarlicki (2010), have also conducted an appropriate study to measure the behaviour and attitude of the customer with the employee. On the other hand, employee empowerment has positively influenced organizational performance. In addition, EE has changed the relationship between customer feedback and organizational performance (Kipfelsberger \& Bruch, 2014; Menges \& Ahlquist, 2011). According to reviewed previous literature, I didn't see a single study on FFI in Pakistan. We cannot neglect Pakistani FFI because it is much contributing to our economy. Meanwhile, the main objectives of the present research study are as following; to investigate the individual and collective influence of CS, PSQ, CR and CL on OH of Pakistani FFI. Moreover, second is to evaluate how EE as a moderator rule makes more strength between the relationship of CFB and $\mathrm{OH}$. Third one is that how EE individually influence to an OH Pakistani FFI perspective. Because Pakistan is developing country, there economically growing population makes changes food habits and another hand, mostly international fast food brand is quite coming at different cities since from last decade. Thus, Pakistani investors are more focus FFI with raising fast-food demand; hence, we have preferred FFI for the current study. For takes actual outcomes, we have collected data from fast-food clients, their managers \&other workers.

The consequences based on the following approaches; We have used Factor Wise Reliability (FWR) method to test questions reliability; Descriptive Statistics to verifies the data normality distributed; Pearson correlation to check the variables association-ship; Multiple linear regression technique (MLRE) to diagnoses per-point and overall fraction between dependent and independent variables; finally uses of simple linear regression moderation equation (SLRME) for examines the moderation effect.

The remaining part of this paper has consisted of the following sections. Section 2 reviews the literature concerning on $\mathrm{OH}, \mathrm{CFB}$ and $\mathrm{EE}$ and construct the research hypothesis for 
present study; Section 3 discusses the research methodology, population, sample data and tools. Section 4 explains the overall findings of the study; Section 5 summarizes and presents the results; finally, Section 6 provides the policy recommendations.

\section{Literature Review \& Design Hypothesis}

From the past several decades, the researchers were working on organizational performance by different perspectives. The main agenda of all researches were growing-up to organizational performance. Moreover, every researcher was concluding his own opinion under the light of their consequences. However, every study has differed on two options from each-others as like "diverse locality" \& "diverse dimensionality. But the present research study is going to measure the ups and downs due to changes in CFB and EE. Let move on previous parallel literature to acquire the author's point of view.

\subsection{Organizational Health}

Quick and unpredictable advancement of technology and growing global competition is primarily required to more intention on $\mathrm{OH}$ for long term benefits. A healthy organization must attain its own goals within a sustainable environment (Nobahar \& Tamadon, 2016). Organizational Health $(\mathrm{OH})$ could be defined as "a healthy organization not only focuses on the financial performance of an organization also emphasizes on the moral aspect, communication capability, goal focus, resource utilization, innovations and problem-solving capability. In the past, Bruhn (2001), has addressed as a healthy organization always conscious of improving their employee's health and customer loyalty. Moreover, (Cartwright \& Cooper, 2014; Quick et al., 2007; Tetrick, 2002), have exposed whom those organizations maintain their vitality, productivity, and competitiveness" they are direct and indirect supporting to our OH. Previously, Kipfelsberger, Herhausen, and Bruch (2016) have determined that positive CFB is essential to promote organizational health. In addition, there it might be the possibility of two types of CFB as following positive CFB as well as negative CFB. They have summarized, the positive CFB is pushing-up to $\mathrm{OH}$ but the negative $\mathrm{CFB}$ pull-down to $\mathrm{OH}$. Moreover, the organizational health phenomenon circulate around following elements goal-focused of organization, optimal utilization of resources, best communication capability, innovativeness and problem-solving skills as well as competitiveness, profitability ratio, vivacity and firms size (Cartwright \& Cooper, 2014; Quick et al., 2007; Sabir et al., 2014; Tetrick, 2002). In the current research study, the scholars are concluded the organizational health with following dementions profitability ratios, problem-solving skills, optimal utilization of resources, competitiveness and firm's size.

\subsection{Customer Feedback}

The term feedback has been explained as useful information or criticism about prior action or behaviour from an individual or group hence they can improve the current situation or further action and self-behaviour by the illumination of market feedback(Williams et al., 2015). Appropriate communication way among human beings is also promoted positive customer feedback because pleasant communication way might be more value-added rather than 
sharing information by using ridicules way of talking (Mets, 2002; Sydänmaanlakka, 2002; Torokoff \& Mets, 2005; Zwell, 2000).

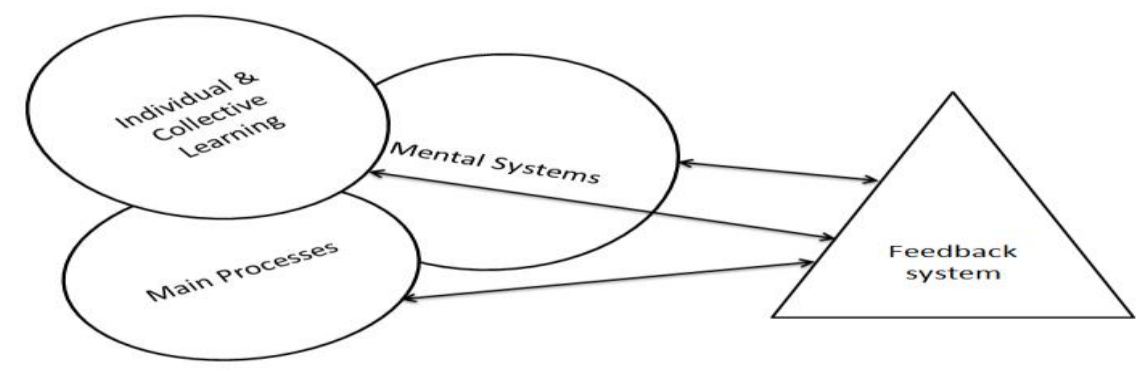

Figure 1. Framework for organizational development and its link to the feedback system (Mets, 2002). Individual and collective learning, main processes and mental system are three best elements of the feedback system and consequently, organizational development \& feedback both have interdependent (Mets, 2002)

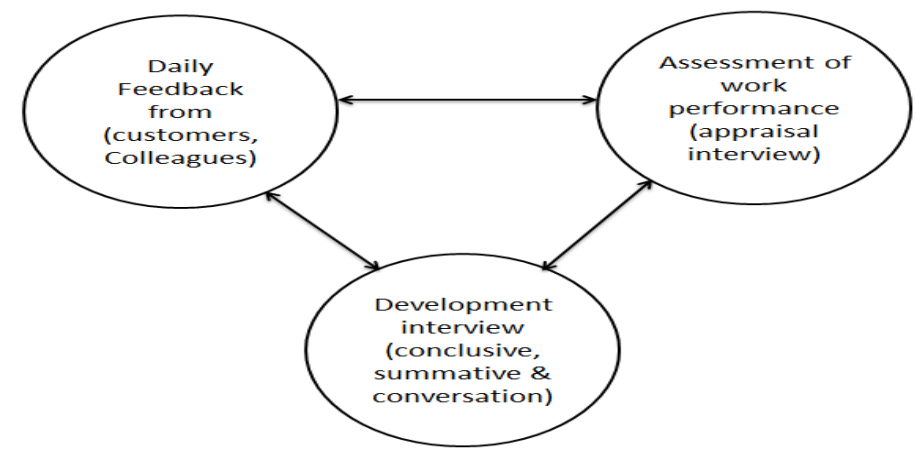

Figure 2. Mutual impact of the parts of feedback (Torokoff, 2006)

Figure 2 indicates that an appraisal interview, feedback and growing debate type of feedback system depends on organizational goals. Moreover, an ideal administration always follows its steady organizational goals (Türk, 2001; Woodman \& Pasmore, 2002). Overall, a particular organization and its development depend on the feedback system. They have learned by gathering feedback and then set the primary goals for future work, and frequently it's repeated the process for growing purpose. Every element of the feedback system is equally important and makes sure its consistency, and that's also comforting for enrolled employees. In the past, Kipfelsberger et al. (2016), have determined that the CFB might be two types as positive $\mathrm{CFB}$ and negative $\mathrm{CFB}$, so first one is worthy for organization and its progress, but in the form of negative CFB it can be worst for OH. So it can be eliminated by tuning into your disappointed customer through acknowledged criticism and realized them we will work with you in any situation and we will provide the whole facilities. In addition, Ozcelik, Akan, and Surucuoglu (2007) have conducted a research study on FFI performance via gender base CFB. They were finalized total 400 sample size and dividing sample on gender as 200 on male and 200 on female, and they determined 26.65 average years old peoples willing to eat fast food deals. De Haan, Verhoef, and Wiesel (2015), have found that CFB is positively 
associated with CS and CR in the area of extensive industry. For this purpose, they were summarized data from 93 firms of 18 different sectors. Daodao is the best source of CFB as Trip Advisor for CFB of Chinese hotel brands and international hotel brands respectively (Schuckert, Liang, Law, \& Sun, 2019). They have found that nowadays, China is more focus on luxury hotels due to luxury people's demand. Jones et al. 2011), have addressed that CS, PSQ, CR \& CL are vital dimensions of CFB in FFI. Mainly, they have also indicated the PSQ does enhance the CS and its pulling to CR and CL. Furthermore, Kipfelsberger et al. (2016), have explained that two types of CFB, like positive CFB as well as negative CFB. So Positive CFB is worthy for every organization, especially in growing prospective, but negative $\mathrm{CFB}$ has the cause of worst for $\mathrm{OH}$. Thus, when appearing negative $\mathrm{CFB}$ it can be eliminates via tuning your disappointed customer, provide excellent PSQ, much more focus on CS, acknowledged there criticism.

H1: There is a positive and significant relationship between Organizational health customer feedbacks.

\subsubsection{Customer Satisfaction}

Customer satisfaction is more obligations for every business sector. Moreover, the FFI is a place where clients have more focused and once-time a day visit for eatery purpose while customer satisfaction is very mandatory for revisiting clients. International and local restaurant chains are satisfying the high demand of customers in a variety of products and services. In the modern era, the world has dwindling culture and habits due to the extensive use of social and electronic media. So the eating behaviour has probably similar across the globe, hence the main reason for such a massive spread of the restaurant industry in the world (Sabir et al., 2014). Dimensionally, various scholars have expressed that the Perceived value, affective response, fulfilling changing and new needs, fulfilling essential needs and price transparency and its reliability as dimensions of customer's satisfaction. Customer satisfaction can mean very different things among to the answerer. It may include such factors as delivery time, price, conformity, professionalism, or it is generally just a response to customer' requests (Suchánek \& Králová, 2015).

H1a: There is a positive and significant relationship between customer satisfaction and organizational health

\subsubsection{Perceived Service Quality}

Inside eatery business has not been exempted from either expanded rivalry or client interest for high administration quality. These days, clients have a wide variety of eatery administrations to browse, and administration quality conditions positively affect an aggressive eatery advantage. In the past, Ramseook-Munhurrun (2012), has estimated eatery business especially, appraise the quality and seems essential parts in enterprises with high client inclusion. Clients have very inspired by reliable administration and its quick service delivery (Korda \& Snoj, 2010). To recognize the quality benefit, this has circulated between client desires delivered by eatery administration and real execution of the administration (Arun Parasuraman, Berry, \& Zeithaml, 1993). 


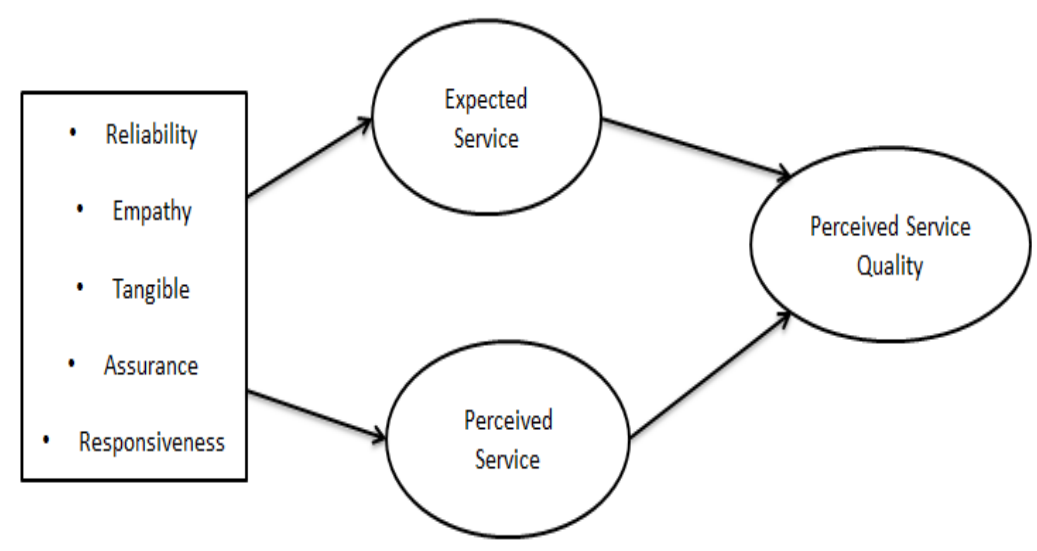

Figure 3. Service Quality Model SQM (Ananthanarayanan Parasuraman, Zeithaml, \& Berry, 1988)

In figure 3, it has mentioned PSQ dimensions like as reliability, empathy, tangibles, assurance and responsiveness. The conflict is in between expected \&perceived services.

\begin{tabular}{|l|l|}
\hline Dimension & \multicolumn{1}{|c|}{ Definition } \\
\hline Empathy & $\begin{array}{l}\text { Caring, easy access, excellent communication, customer understanding and } \\
\text { individualized attention given to customers. }\end{array}$ \\
\hline Assurance & Employees' knowledge and courtesy and their ability to inspire trust and confidence. \\
\hline Responsiveness & Willingness to help customers and provide prompt service. \\
\hline Reliability & Ability to perform the promised service dependably and accurately. \\
\hline Tangibles & The appearance of physical facilities, equipment, personnel and written materials. \\
\hline
\end{tabular}

Source: Adapted from the study of (Alamgir \& Shamsuddoha, 2004)

In addition, Korda and Snoj (2010), was also used the same model of perceived service quality model and its dimensions. Consequently, the present research study has also taken above aspects of respective past scholars.

H1b: There is a significant and positive relationship between Perceived service quality (PSQ) and Organizational Health $(\mathrm{OH})$.

\subsubsection{Customer Retention}

Oliver (1997), has addressed that customer retention (CR) is a common terminology which is mostly used when retaining a particular customer or don't move to another. He has mentioned customer loyalty (CL) to push up to customer for customer retention. We can't deny that CR is complicated to hold-down, they have to stay or re-buy some commodities with high commitment, and there are so many market forces and other factors to insist the customers make the change on new locality. In days, FFI is extremely deviated or vibrant and requires more focus on innovation as regarding customer needs (Oliver, Rust, \& Varki, 1997). Previously, Khan (2013), has estimated the Pakistani hotel industry, he has mentioned hotel 
administration offered different packages regarding per buffet charges and other services to the customer to getting customer retention. The expectation of repurchasing, Financial consciousness, Convenient atmosphere, Recommended to others \& overall satisfaction have prominent dimensions of CR by (Syaqirah \& Faizurrahman, 2014). According to various scholars, these five dimensions are the best system to explore the CR.

H1c: There is a significant and positive relationship between customer retention and organizational health

\subsubsection{Customer Loyalty}

In today's changing world, every business is looking to accomplish a competitive advantage; they want much more customer loyalty \& promote business efficiency. With more options for the ever more challenging customers, restaurant businesses face some intense competition. Restaurant owners and managers recognize that loyal customers are worth a great compact more than just everyday customers-even if those are once-in-awhile customers (Mattila, 2001). High-class restaurants have advanced and aggressive competition and which one has customer loyalty make a decisive advantage from them. Customer loyalty is a prime determinant of the long-term financial performance of the restaurant operators. Increased reliability can substantially increase profits in the service industry restaurants.

Similarly, in the modern era, every business holder is willing to acquire proficiency in customer loyalty even though they are doing services business or any other. It has argued that it can be five or six times more expensive to achieve a new customer than to retain one. A loyal customer is a buyer who repurchases from the same service organization whenever possible, who continues to recommend and who maintains a positive attitude toward the service provider (Behremen \& Doğdubay, 2015). Uni-dimensional, Bi-dimensional and Multi-dimensional approaches have significant customer dimensions loyalty (Bobâlcă, 2013).

\subsubsection{Uni-dimensional Approach}

Earlier 1970, the concept of people against brand loyalty it was just to re-buying something at the same place. Jacoby and Kyner (1973), have endured expanding to a uni-dimensional approach whenever the bi-dimensional model was on the initial stage

\subsubsection{Bi-dimensional Approach}

The bi-dimensional was comprised of customer attitude and behaviour. After 1970, several studies were conducted to evaluate the criteria of customers loyalty by using different customer segments (Baloglu, 2002).

In the last decade was introduced multi-dimensional model, behavioural, cognitive, conative and affective loyalty has used by multi-dimensional approach (Åkerlund, 2004)

H1d: There is a significant and positive relationship between customer loyalty and organizational health. 


\subsection{Employee Empowerment}

Numerous organizations are given many opportunities to their employees to ascertain their skills for achieving short-term and long-term goals. Those organizations are poor conditions, and they should urgently need to concentrate on EE and profession satisfaction in their leadership to accomplish such their desires (Jacquiline, 2014). EE is one of the esteemed ideas that are thought to be essential to promote the behavioural components of workers to accomplish "higher level of service, advancement, collaboration feeling, business enterprise, fearlessness, and feel rational" (Elnaga \& Imran, 2014). In a study by Hunjra, Ul Haq, Akbar, and Yousaf (2011) have analysed that EE is an earlier characterize as the ability to a representative to well manage to customer choices and its job satisfaction to promote organizational performance. Additionally, Daft (2001), has described empowerment as offering worker the flexibility, control, and chances for leadership and authoritative to resolve the issues. Empowerment is worked by planning on a specific workplace where employees are permitted to settle on their own choices in light of certain business-related conditions and one other side empowerment to enhance the innovation probability (Hanaysha, 2016). Wadhwa and Verghese (2015) have concluded that empowerment is a procedure of sharing authority with obligation and responsibility to workers through their supervisor. To accomplish the organizational goals has contained an optimal order to capacity \& advance employee efficiency of individual and group capability (GanjiNia, Gilaninia, \& Sharami, 2013).

In the modern era where enhancing the competition day by day is to certain establish robust and productive strategies to get the optimal level of productivity. Moreover, the author funded that EE is also positively influenced by PSQ (Timothy \& Abubakar, 2013). Kipfelsberger et al. (2016), was estimated EE climate makes more strengthen the relationship between positive CFB \& OH. Furthermore, Surrender control, Create buy-in, source new ideas, get the employee vote \& create team have dimensions of EE (Musselwhite, 2007). See technically then we realized that the employees feeling look like a personal business by give more respect and acknowledged appropriate there ideas, give more respect and consider a part of a team.

In addition, EE is widely viewed as a dynamic concept to improve service quality and operational efficiency in the hospitality industry (Kele, Mohsin, \& Lengler, 2017). Several studies have conducted on EE in the different zone but its concept not clear. For this purpose, 22 times data collected via a semi-structured interview with employees, supervisors and managers from five-star hotels of Malaysia. Hancer and George (2003b), have determined the psychological employee empowerment in 24 hours restaurants (FFI) and according to the scholar, the research instrument used in this study was first developed by Spreitzer (unpublished doctoral dissertation, University of Michigan, 1992) and modified by (Fulford and Enz, 1995). Subjects of the survey represented three restaurant chains in Midwest United States. Nine hundred twenty-four surveys from 66 units were received representing a $46.2 \%$ usable response rate.

H2: Employee Empowerment can make more strengthened the relationship between customer 
feedback \& organizational health.

H3: There is a positive and significant relationship between employee empowerment organizational health.

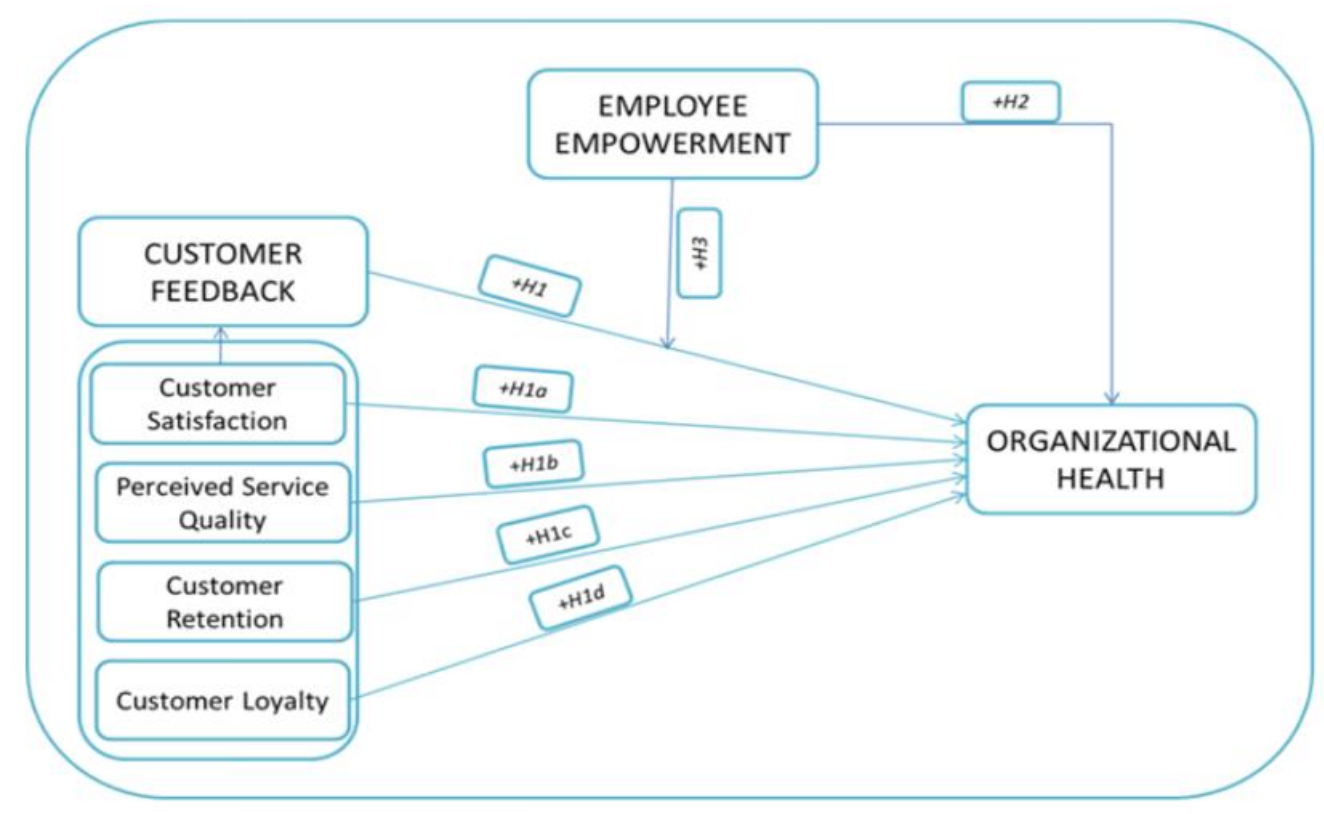

Figure 4. Conceptual Framework

Note: Conceptual Model is the best instrument to get an overview of the study and its conjunction of the variables. The current conceptual model has summarized on significant three variables as following Organizational health (DV), Customer feedback (IV) \& Employee empowerment (MV). In addition, entire conceptual framework has summarized all previous studies in an imperial current research study regarding subject.

\section{Research Methodology}

After the literature review, it was easy to adopt a convenient research methodology for the empirical research study. The present research methodology was comprised on following methods Factor Wise Reliability (FWR) approach to test questions reliability; Descriptive Statistics to verifies the data normality distributed; Pearson correlation to check the variables association-ship; Multiple linear regression technique (MLRE) to diagnoses per-point and overall fraction between dependent and independent variables; finally uses of simple linear regression moderation equation (SLRME) for examines the moderation effect. This research methodology idea was taken from (Aktar, Sachu, \& Ali, 2012; Khan, 2013; Kipfelsberger et al., 2016; Timothy \& Abubakar, 2013).

\subsection{Questionnaire Design}

Research questionnaire is an integral part of empirical research so that should be simple, validated and reliable. So present research questionnaire consisted on four parts, first part on 
demographics evidence; second part on Costumer Feedback (CFB); third part on Organizational Health $(\mathrm{OH})$ and fourth part on Employee Empowerment (EE). Noteworthy, Part one \& two of the questionnaire have summarized on personal information and customer feedback which filled by Fast Food user; one and three have contained personal information and organizational health which obtained by Fast Food Managers; one and four-part have consisted on personal details and Employee Empowerment which collected by employees of FFI. All questions of the present research study were adopted by different sources and modified regarding own respected review. So our research questionnaire brings from; CS was taken from (Hancer \& George, 2003a); PSQ was taken from (Archakova, 2013); CR was taken from (Scarff, 2017); CL was taken from (Khadka \& Maharjan, 2017); EE was taken from (Makinda) \& (Busara, 2016).

\subsection{Population \& Sampling}

Nowadays, quick-changing eating behaviour of Pakistan people's with a growing economy. The Fast Food trend is increased day by day in Pakistan. So "Papa's Kitchen, Lataska, Fri-chicks, Almaida, Chicken Cottage, Pizza Hut, McDonald's, Hardee's, KFC \& Subway" have a major brand of Fast Food Industry (FFI) in Pakistan This research study was conducted on Bahawalpur Division of Pakistan. Moreover, Bahawalpur Division has contained on comprehensive three major districts, and each district has a lot of cities, and each city has the number of Fast Food points. Quantitatively, overall544 main Fast Food points are available in the area of Bahawalpur Division. For such an imperative objective, we have targeted 250 main Fast Food Points for data collection and filled questionnaire by respondents. In this way, data were summarized from 250 Fast Food users; 250 Branch Managers and 250 other Employees so total have 750 numbers of respondents. Comrey and Lee (1992); Pearson and Mundform (2010) have addressed the criteria of sample size like as 50 number of respondents are considered very weak; 100 is weak, 200 is fair, 300 is good, 500 is very good, and 1,000 or more is excellent. Sabir et al. (2014), have also conducted an empirical study on CS at FFI of Pakistan by taking 130 sample sizes.

\subsection{Data Screening}

Before data analysis, we made sure the following kind of steps; first was visualize the missing items, the second was whether questions reliable or not, third was normal data distributed. Wells and Wollack (2003), has addressed that Factor Wise Reliability Statistics is a suitable tool to measures the consistency of questions. Horst (1953), has certified that questions of a variable will be acknowledged if the Cronbach Alpha value is higher than 0.52. Furthermore, after that study was confirmed to the normality of the data by using descriptive statistics. Lendoiro et al. (2012), Singh and Sharma (2016) were suggested to examine the data normality by using descriptive statistic seems to skewness and Kurtosis values. They have emphasized if the absolute kurtosis and skewness is less than \pm 2 , so normality is acceptable. Moreover, after reliability and normality investigations that study was going to be on the next stage as diagnose individual and collective association of the variables. 


\subsection{Statistical Techniques}

Present research methodology has comprised of following statistical techniques "Factor Wise and Simple Moderation Regression equations to diagnose moderation effect. In the previous section, we have already addressed to factor wise reliability, and descriptive statistics hence let's move on the next section as;

\subsubsection{Pearson Correlation Test}

Pearson Correlation test has applied to assess the individual variable influence. Kipfelsberger et al. (2016), also has an underutilized Pearson correlation test to measure the individual impact in between customer feedback and Organizational Health. Various scholars recommended the Pearson Correlation technique to check the personal effect. So individual effect could be measured by the following formula;

$$
\left(\mathrm{X}_{\mathrm{i}} \mathrm{Y}_{\mathrm{i}}\right)=\frac{\sum_{\mathrm{i}=1}^{\mathrm{n}}\left[\left(\mathrm{X}_{\mathrm{i}}-\bar{X}\right)\left(\mathrm{Y}_{\mathrm{i}}-\bar{Y}\right)\right]}{\sqrt{\sum_{\mathrm{i}=1}^{\mathrm{n}}\left(\mathrm{X}_{\mathrm{i}}-\bar{X}\right)^{2}} \sqrt{\sum_{\mathrm{i}=1}^{\mathrm{n}}\left(\mathrm{Y}_{\mathrm{i}}-\bar{Y}\right)^{2}}}
$$

Initially, the Pearson Correlation Formula comes down to dividing the covariance by the product of the Standard deviation. Generally, for considerate here x \& y are considered two variables.

\subsubsection{Regression Analysis}

Has a most excellent tool to estimate how much deviate in the dependent variable due to per point change explanatory variable. Moreover, regression analysis is also addressed the collective effect of explanatory variables on the dependent variable. Additionally, Eliwa (2006) has tried to test the relationship between customer royalty \& image of fine dining restaurant by applying regression technique. Afterwards, Ashraf, Sajjad, Ridwan, Ahmed, and Nazeer (2013), has also tried to evaluate the determinants of consumer complaining behavior on Pakistan region by using regression analysis technique. Customers might appreciate to employees, and they could be enhance working efficiency by whether decent attitude or cash reward (Aktar et al., 2012). Thus, Econometric Multiple Linear Regression Equation (ELRE);

$$
\sum_{\mathrm{i}=1}^{\mathrm{n}} \widehat{O H}=\alpha_{0}+\beta_{\mathrm{j}} \mathrm{CS}_{\mathrm{it}}+\beta_{\mathrm{k}} \mathrm{PSQ}_{\mathrm{it}}+\beta_{\mathrm{l}} \mathrm{CR}_{\mathrm{it}}+\beta_{\mathrm{m}} \mathrm{CL}_{\mathrm{it}}+\mu_{\mathrm{it}}
$$

In equation (2) was quantified as $n=$ total number of observations, $i=$ number of explanatory variables, $\alpha=$ constant, $\beta=$ coefficients, $y=$ dependent variable, "CS, PSC, CR, \& CL"= explanatory variables $\& \mu=$ stochastic error.

\subsubsection{Simple Moderation Regression Equation}

Appearance of moderator effect it might be promised when DV and IV both variables have interconnected to each other. Understanding of moderation effect comes along withan interaction effect where the third variable (Moderator) change the relationship between dependent and independent variables. Probability of variation can be as such form; 
Note: when growing the third variable would also raise the association level between dependent \& independent variables, is known as "Enhancing Effect". When the relationship is opposite among third and dependent \& Independent variables, is known as "Buffering Effect".

Kipfelsberger et al. (2016), was conducted a research study where EE was used as a moderation rule between $\mathrm{CFB} \& \mathrm{OH}$. Before we need to recognize all variables are on the standardized form, which makes straight forward interpretations afterwards. According to the researcher if both interaction term and predictor variable have become significant, thus, seem full moderation effect. Furthermore, if the predictor variable has significant, but the interaction term has not significant while the main effect is significant.

$$
\text { Interaction Term }=\mathrm{IV} \times \mathrm{MV}
$$

\subsection{Process Macro Approach}

Process is an observed variable OLS and logistic regression path analysis modeling tool. It is widely used through the social, business, and health sciences for estimating direct and indirect effects in single and multiple mediator models. Process is enable to earlier use in SPSS but since 2020 schlars have enabled to measure by R. The process Macro was compised by Andrew F. Hayes.

\section{Results \& Discussion}

Results and discussion unit has undertaken as following outcomes "questions reliability, data normality, variables association \& power of variables and good-fit of the model and moderation effect. Here, lets we described one by on as;

Table 1. Factor wise reliability statistics

\begin{tabular}{|l|l|l|}
\hline Name of the Factor & Cronbach Alpha & No of Items \\
\hline CS & 0.686 & 5 \\
\hline PSQ & 0.658 & 4 \\
\hline CR & 0.649 & 5 \\
\hline CL & 0.661 & 5 \\
\hline OH & 0.735 & 5 \\
\hline EE & 0.767 & 5 \\
\hline
\end{tabular}

Current research study has applied SPSS 21 version to test the consistency of questions. Furthermore, Wells and Wollack (2003), have confirmed that Factor Wise Reliability Statistics is a powerful tool to measures the consistency of questions. Horst (1953), has certified that questions of a variable will be acknowledged if the Cronbach Alpha value is greater than 0.52. According to table-1 (CS=0.686; $\mathrm{PSQ}=0.658 ; \mathrm{CR}=0.649 ; \mathrm{CL}=0.661$; $\mathrm{OH}=0.735 \& \mathrm{EE}=0.767$ ) Cronbach Alpha Values have greater than 0.60 so it is an insinuation to move-up on next stride. 
Table 2. Descriptive statistics

\begin{tabular}{|l|l|l|l|l|l|l|l|l|}
\hline Variables & N & Minimum & Maximum & Mean & Skewness & & Kurtosis & \\
\hline & Statistic & Statistic & Statistic & Statistic & Statistic & Std.Error & Statistic & Std.Error \\
\hline CS & 250 & 1.6 & 4.4 & 3.2168 & 0.026 & 0.154 & -0.435 & 0.307 \\
\hline PSQ & 250 & 1.5 & 4.5 & 3.098 & -0.104 & 0.154 & -0.159 & 0.307 \\
\hline CR & 250 & 1.6 & 5 & 3.6168 & -0.19 & 0.154 & 0.42 & 0.307 \\
\hline CL & 250 & 1.2 & 4.2 & 2.8568 & -0.269 & 0.154 & -0.089 & 0.307 \\
\hline OH & 250 & 1.4 & 4.4 & 3.2008 & -0.172 & 0.154 & -0.537 & 0.307 \\
\hline EE & 250 & 1.2 & 4.8 & 3.1568 & -0.226 & 0.154 & -0.003 & 0.307 \\
\hline CFB & 250 & 2.03 & 4.28 & 3.1971 & -0.084 & 0.154 & -0.309 & 0.307 \\
\hline
\end{tabular}

Note: Normality of a particular dataset has tested on $5 \%$ level.

Table-2 shows the descriptive test to determine on a particular dataset by using skewness and kurtosis statistic. We acknowledged that there are several approaches to calculate whether a specific dataset is normally distributed or not, but a descriptive statistic is much validated from them. In the previous study, Aktar et al. (2012) were also used this technique to measure the normality of data. The entire research study has also seemed with skewness and kurtosis statistic to measure the normality of data. Doane and Seward (2011), were declared a selection criterion of normality of data as if the values of skewness and kurtosis falls in between \pm 1 and \pm 3 respectively, then data would be considered as normal. Moreover, Singh and Sharma (2016) also addressed the selection criteria of normality as if the absolute skewness and kurtosis are less than \pm 2 , so normality is acceptable. On behalf of table-2, the normality has accepted because absolute skewness and kurtosis values of variables CS, PQS, $\mathrm{CR}, \mathrm{CL}, \mathrm{OH}, \mathrm{EE} \& \mathrm{CFB}$ are fall in between \pm 1 and \pm 3 and also lay into \pm 2 .

Table 3. Pearson correlation

\begin{tabular}{|l|l|l|l|l|l|l|l|l|}
\hline \multicolumn{2}{|l|}{ Test } & CS & PSQ & CR & CL & OH & EE & CFB \\
\hline CS & Pearson Correlation & 1 & & & & & & \\
\hline PSQ & Pearson Correlation & $.534^{* *}$ & 1 & & & & & \\
\hline CR & Pearson Correlation & $-0.005^{* *}$ & 0.03 & 1 & & & & \\
\hline CL & Pearson Correlation & $.757^{* *}$ & $.275^{* *}$ & $-0.053^{* *}$ & 1 & & & \\
\hline OH & Pearson Correlation & $.943^{* *}$ & $.506^{* *}$ & $0.027^{* *}$ & $.809^{* *}$ & 1 & & \\
\hline EE & Pearson Correlation & $.778^{* *}$ & $.228^{* *}$ & -0.018 & $.972^{* *}$ & $.854^{* *}$ & 1 & \\
\hline CFB & Pearson Correlation & $.861^{* *}$ & $.700^{* *}$ & $.357^{* *}$ & $.741^{* *}$ & $.860^{* *}$ & $.733^{* *}$ & 1 \\
\hline
\end{tabular}

Note: Single *Correlation is significant at the 0.05 level; double ** Correlation is significant at the 0.01 level

Table-3 shows that individual association among two categorical variables at $5 \%$ and $10 \%$ critical level. Kipfelsberger et al. (2016), has also measured Positive \& negative CFB with $\mathrm{OH}$ by using Pearson Correlation technique. The Pearson correlation addresses the linear relationship between categorical variables, e.g., CS, CSQ, CR, CL, CFB, EE \& OH. In table-3 each numeric value has associated with single and double staric hence single * exhibits on 5\% significance level as well as double ** exhibits10\%significant level. Noteworthy, more excellent statistic value shows high power of significant and lower value 
shows that less power of significant of particular variables.

\subsection{Linear Regression Approach}

Table 4. Coefficients

\begin{tabular}{|l|l|l|l|l|l|l|l|}
\hline \multirow{3}{*}{ Model } & \multicolumn{2}{|l|}{$\begin{array}{l}\text { Unstandardized } \\
\text { Coefficients }\end{array}$} & $\begin{array}{l}\text { Standardized } \\
\text { Coefficients }\end{array}$ & \multirow{2}{*}{$\mathrm{t}$} & \multirow{2}{*}{ Sig. } & \multicolumn{2}{|l|}{ Collinearity Statistics } \\
\cline { 2 - 6 } \cline { 7 - 9 } & $\mathrm{B}$ & Std.Error & Beta & & & Tolerance & VIF \\
\hline (Constant) & -0.368 & 0.107 & - & -3.433 & 0.001 & - & - \\
\hline CS & 0.777 & 0.035 & 0.736 & 21.924 & 0.000 & 0.312 & 3.201 \\
\hline PSQ & 0.047 & 0.024 & 0.045 & 1.988 & 0.048 & 0.676 & 1.48 \\
\hline CR & 0.046 & 0.021 & 0.042 & 2.244 & 0.026 & 0.994 & 1.006 \\
\hline CL & 0.264 & 0.032 & 0.241 & 8.149 & 0.000 & 0.403 & 2.484 \\
\hline
\end{tabular}

Notes: $\mathrm{R}=.956 ; \mathrm{R}$ square $=.914 ;$ adjusted $\mathrm{R}$ square $=.912 ; \mathrm{F}=647.970 ; \mathrm{D}-\mathrm{W}=2.696 * *$ Significance $\mathrm{p}<.01$

Regression test considered the best statistical approach to measure continues numerical dataset, especially in the research field. Regression analysis used to determine per unit change and overall influence of explanatory variables on the dependent variable. Aktar et al. (2012), was estimated the impact of paying rewards attention to the performance of employees in Commercial Banks of Bangladesh by using regression analysis approach. The outcome shows that there is positive \& significant association-ship between paying rewards attention and employee's performance. As the previous study, Khan (2013) has explored the determinants of customer retention in the Hotel Industry of Pakistan by applying regression technique. Therefore, regression analysis is a reliable\& effected technique in business studies. However, wedrag this research technique to the attained actual outcome. Consequently, $R^{2}=$ .914 are indicating that the explanatory variables (CS, CSQ, CR, CL) have91.4\% described to the dependent variable (Organizational Health). Moreover, $\mathrm{P}<0.01$ of F-statistic, which indicates a good fit of the model. Furthermore, $\mathrm{DW}=2.696$ to means that the entire model is free from the autocorrelation problem. Collinearity statistics VIF $<10 \%$ \&Tolerance $>0.2$ shows that our model free from error of Multicollinearity. Additionally, Coefficient Values of explanatory variables are $\mathrm{CS}=0.777, \mathrm{PSQ}=0.047, \mathrm{CRT}=0.046 \& \mathrm{CL}=0.264$, which indicates that per-unit power of association along with dependent veritable. Here $\mathrm{P}<0.05 ; \mathrm{T}>2$ shows that all explanatory variables are positively associated along with the dependent variable. So outcomes in table-4 were acknowledged to accepted alternative hypothesis and reject the null hypothesis.

H1a: There is a positive and significant relationship between Customer satisfaction (CS) and Organizational Health $(\mathrm{OH})$.

H1b: There is a positive and significant relationship between Perceived service quality (PSQ) and Organizational Health $(\mathrm{OH})$.

H1c: There is a positive and significant relationship between Customer retention (CR) and Organizational Health $(\mathrm{OH})$.

H1d: There is a positive and significant relationship between Customer Loyalty (CL) and 
Organizational Health $(\mathrm{OH})$.

In addition, rejected null hypothesis and accepted alternative hypothesis $\mathrm{H} 1 \mathrm{a}, \mathrm{H} 1 \mathrm{~b}, \mathrm{H} 1 \mathrm{c}$ and $\mathrm{H} 1 \mathrm{~d}$ have emphasized the productive and positive CFB that ultimately will promoting to $\mathrm{OH}$ Kipfelsberger et al. (2016).

Table 5. Coefficients

\begin{tabular}{|l|l|l|l|l|l|}
\hline \multirow{2}{*}{ Model } & \multicolumn{2}{|l|}{ Unstandardized Coefficients } & Standardized Coefficients & \multirow{2}{*}{ t } & \multirow{2}{*}{ Sig. } \\
\cline { 2 - 6 } & $\mathrm{B}$ & Std. Error & Beta & & \\
\hline (Constant) & -1.213 & 0.168 & - & -7.216 & 0.000 \\
\hline CFB & 1.381 & 0.052 & 0.86 & 26.529 & 0.000 \\
\hline
\end{tabular}

Note; $\mathrm{R}=.860 ; \mathrm{R}$ square $=.739 ; \mathrm{F}=703.808(\mathrm{p}<0.01) ; \mathrm{D}-\mathrm{W}=2.300 * *$ Significance, $\mathrm{p}<.01$

Table-5 explained the relationship between Explanatory variable $\mathrm{CFB}$ and $\mathrm{OH}$. The coefficient value recognizes per-unit variation between regressed variables by using $\mathrm{P}$ and $\mathrm{T}$ values, hence, $\mathrm{B}=1.381$ which means that 1.381 -unit variation in $\mathrm{OH}$ due to 1-unitchangein CFB. Moreover, R-square value indicates that $74 \% \mathrm{OH}$ has explained by CFB. Besides, on the other hand, F-statistic valueis $\mathrm{P}<0.01$, which shows that good fit of the model. By under illumination of table-5, we have been diagnosed both variables CFB \& OH was positively associated with one another. However, we can reject the null hypothesis and accept the alternative hypothesis.

H1: There is a positive and significant relationship between positive Customer Feedback (CFB) and Organizational Health $(\mathrm{OH})$.

Table 6. Moderation effect

\begin{tabular}{|c|c|c|c|c|c|c|c|}
\hline Model & $\begin{array}{l}\text { Unstandardized } \\
\text { Coefficients }\end{array}$ & & $\begin{array}{l}\text { Standardized } \\
\text { Coefficients }\end{array}$ & $\mathrm{T}$ & Sig. & \multicolumn{2}{|c|}{$\begin{array}{l}\text { Collinearity } \\
\text { Statistics }\end{array}$} \\
\hline & $\mathrm{B}$ & Std.Error & Beta & & & Tolerance & VIF \\
\hline (Constant) & 0.459 & 0.187 & - & 2.459 & 0.015 & - & - \\
\hline CFB & 0.42 & 0.086 & 0.261 & 4.863 & 0.000 & 0.222 & 4.507 \\
\hline CFB*EE & 0.135 & 0.011 & 0.678 & 12.621 & 0.000 & 0.222 & 4.507 \\
\hline
\end{tabular}

Note; $\mathrm{R}=.917 ; \mathrm{R}$ square $=.842 ; \mathrm{F}=656.156(\mathrm{p}<0.01) ; \mathrm{D}-\mathrm{W}=1.898 ; * *$ Significance, $\mathrm{p}<.01$

Baron and Kenny (1986), was fundamental utilized simple linear moderation regression equation to test the moderation effect. They certified if the interaction term has become significant with the explanatory variable; thus, moderation effect fall-down in the model it might be positive as well as negative. Previously, Timothy and Abubakar (2013), was conducted an empirical research study on Nigerian Baking Industry (NBI), he addressed both variables EE \& NBI have positively associated. Additionally, GanjiNia et al. (2013) have also tested to EE in organizations. They were found that EE to promote appropriate environment \& Innovations.

Furthermore, Kipfelsberger et al. (2016) have analysed how CFB effects to an OH and they 
have categories to CFB into two parts as well as positive CFB and Negative CFB. Similarly, they have taken EE as a Moderator variable, and they have agreed that the employee empowerment climate sort more strengthened between positive CFB \& OH but does not affect the negative CFB and OH. In Table-6, we have diagnosed EE as moderation effect into $\mathrm{CFB} \& \mathrm{OH}$. Under the shed light of consequences, it has been acknowledged EE makes more strengthen to the relationship of $\mathrm{CFB} \& \mathrm{OH}$. Thus, we can see $\mathrm{b}=0.135 ; \mathrm{P}<0.05$ of interaction term has bring significant with explanatory variable CFB. So we are rejecting null hypothesis and accepting alternative hypothesis.

H2: Employee Empowerment (EE) makes more strengthened to customer feedback (CFB) \& organizational health $(\mathrm{OH})$.

Table 7. Coefficients

\begin{tabular}{|l|l|l|l|l|l|}
\hline \multirow{2}{*}{ Model } & \multicolumn{2}{|l|}{ Unstandardized Coefficients } & Standardized Coefficients & \multirow{2}{*}{ t } & \multirow{2}{*}{ Sig. } \\
\cline { 2 - 4 } & $\mathrm{B}$ & Std.Error & Beta & 7.035 & 0.000 \\
\hline (Constant) & 0.702 & 0.1 & - & 25.838 & 0.000 \\
\hline EE & 0.792 & 0.031 & 0.854 & \\
\hline
\end{tabular}

Note; $\mathrm{R}=.854 ; \mathrm{R}$ square $=.729 ; \mathrm{F}=667.597(\mathrm{p}<0.01) ; \mathrm{DW}=1.315 \& * *$ Significance, $\mathrm{p}<.01$

Hunjra et al. (2011), estimated the relationship between EE and Job Satisfaction an empirical study of Pakistani Service Industry by using regression analysis technique. Here we are representing the relationship between $\mathrm{EE} \& \mathrm{OH}$ via regression approach

In table $7 \mathrm{~B}=0.792 ; \mathrm{P}<0.000 ; \mathrm{T}>2$ which is highlighted that when 1-unit variation in $\mathrm{EE}$, then 0.792 -unitcan be variation in $\mathrm{OH}$. Furthermore, $R^{2}=0.729$ which are shows that approximately EE $73 \%$ influences to $\mathrm{OH}$ and $\mathrm{F}$-value is also under 0.01 . Consequences are supporting our hypothesis.

H3: Employee empowerment (EE) is positively associated with organizational health $(\mathrm{OH})$

\subsection{Robustness check of Moderation Effect}

Table 8. Model Summary

\begin{tabular}{|l|l|l|l|l|l|l|}
\hline $\mathrm{R}$ & $\mathrm{R}-\mathrm{sq}$ & $\mathrm{MSE}$ & $\mathrm{F}$ & $\mathrm{df1}$ & $\mathrm{df} 2$ & $\mathrm{p}$ \\
\hline .9205 & .8473 & .0866 & 454.9424 & 3.0000 & 246.0000 & .0000 \\
\hline Model & coeff & $\mathrm{se}$ & $\mathrm{t}$ & $\mathrm{p}$ & LLCI & ULCI \\
\hline constant & -.7123 & .4282 & -1.6634 & .0975 & -1.5558 & .1312 \\
\hline CFB & .7803 & .1463 & 5.3332 & .0000 & .4921 & 1.0685 \\
\hline EE & .4164 & .1376 & 3.0266 & .0027 & .1454 & .6874 \\
\hline Int_1 & .3701 & .4261 & 2.2351 & .0044 & .3107 & .2940 \\
\hline
\end{tabular}

Table 8 indices that overall interaction effect has determined significant because the probability value of in erection effect $<0.005$. Furthermore, the moderation variable has significant with dependent variable while the $\mathrm{p}=.0027$ and $\mathrm{t}>2$. The overall model has become good fit. 


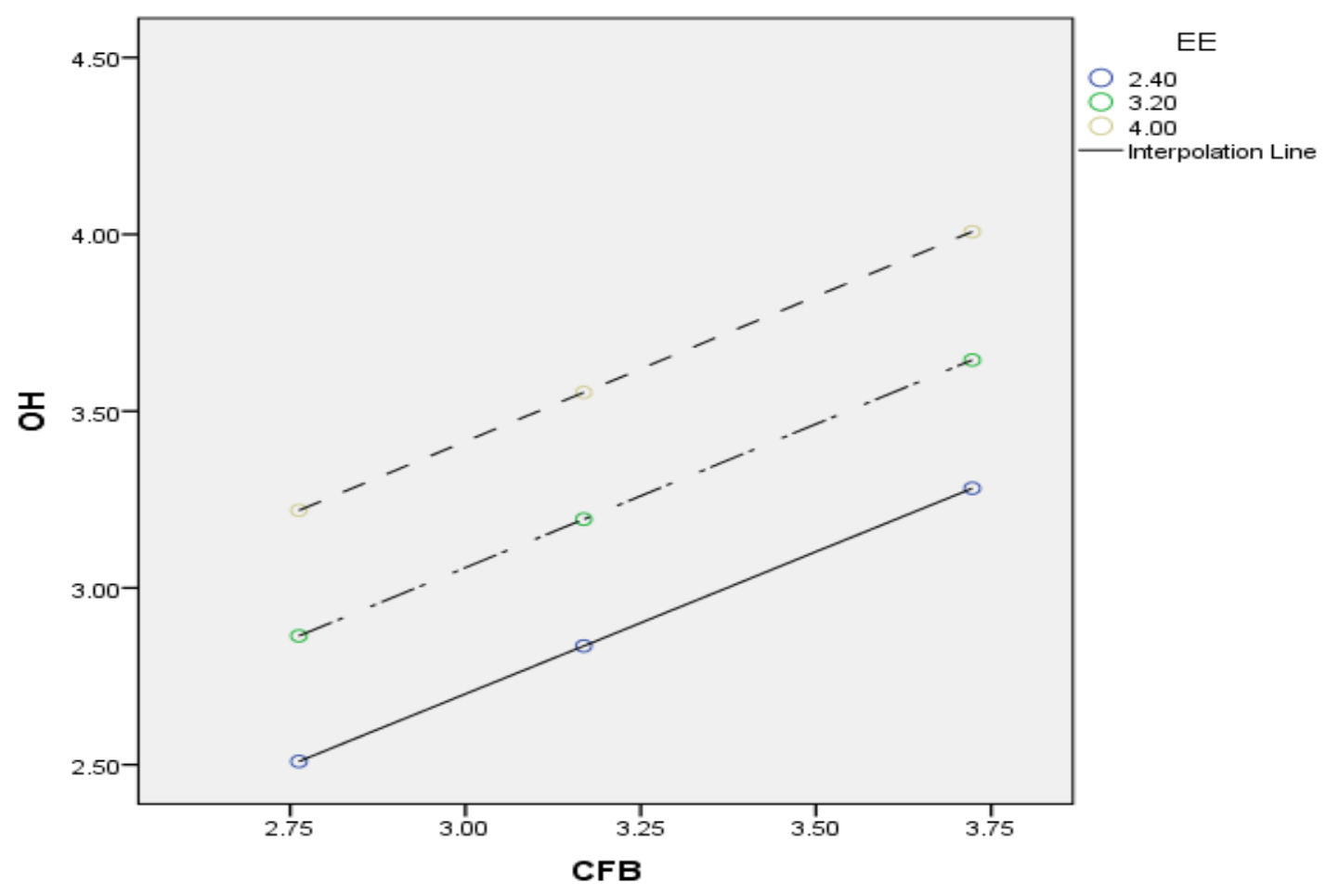

Figure 5. Process-Macro Moderation Approach

Procss-Macro is a very useful and famous approach to examine the mote ration effect among dependent and predictor variable. In figure 5, on Y-axis is dependent variable and $\mathrm{X}$-axis is predictor variable. In addition, on the top right side is showing moderator effects level with different colours circle. There light blow circle shows less moderator effect, light green circle shows mediam moderator effect and light yellow circle shows high moderator effect. Consequentially visualizing indicates that the $\mathrm{EE}$ as a moderator effect has mild incorporated among dependent and predictor variable.

\section{Summary \& Discussion}

The main objective of the present study was explored that the impact of CFB on OH when EE works as a moderator. Primarily, we examine the consistency of the questions via FWRT; after that, we make sure data normality through Descriptive Statistics that we can visualize in table 2. Consequently, table 4indicates that CS, PSQ, CR and CL have positively associated with $\mathrm{OH}$, but $\mathrm{CS}$ is more associated as comparatively. The positive association-ship between $\mathrm{OH}$ and CS, PSQ, CR, CL has been supported with following scholars (Aktar et al., 2012; Khan, 2013; Mattila, 2001; Ramseook-Munhurrun, 2012; Sabir et al., 2014). Furthermore, $\mathrm{CFB}$ is also positively associated with $\mathrm{OH}$ meanwhile entire findings matched with (Kipfelsberger et al., 2016; Mets, 2002; Sydänmaanlakka, 2002; Torokoff \& Mets, 2005; Zwell, 2000). The findings show that when positive CFB raise then $\mathrm{OH}$ also raise because positive CFB increase means indirectly raise up CS PSQ, CR and as well as CL. These consequences are supporting (Timothy \& Abubakar, 2013). Besides, Kipfelsberger et al. (2016), hasconcluded that if you higher management give more authority to our employee's, 
then they can get suitable OH. Furthermore, EE can also acquire customer attention. In the past, Kipfelsberger et al. (2016) have also described that EE makes more strengthen the relationship between $\mathrm{CFB}$ and $\mathrm{OH}$. EE creates more inspiration among employees while they give more attention on our work. Moreover, keeps motion look like a personal business, so they work with full dedication. Pakistani fast-food customers are compassionate concerning product quality, employee behaviour, service quality as well.

\section{Conclusions and Implementation}

The present research study has proposed that there has a positive and significant relationship between Customer feedback (CFB) and organizational health $(\mathrm{OH})$ when EE works as a moderator. The consequences have summarized positive CFB positively influenced to $\mathrm{OH}$ of FFI (Kipfelsberger et al., 2016; Mets, 2002; Sydänmaanlakka, 2002; Zwell, 2000). Noteworthy, increasesin $\mathrm{OH}$ means that extrafocuson organizational goals, optimal utilization of resources, appropriate communication capability, improve innovations and problem-solving skills, (Cartwright \& Cooper, 2014; Quick et al., 2007; Tetrick, 2002). Thus, positive $\mathrm{CFB}$ is must be essential for worthy $\mathrm{OH}$. Now the question is that how the administration of FFI can be improved to CFB so it can be better with following ways; first one it can be possible with enhancing customer CS, PSQ, CR \& CL. The second one makes more authorized to your employees because as the way the relationship between $\mathrm{CFB}$ and $\mathrm{OH}$ will more strengthen-full. This phenomenon has supported previous studies (Kipfelsberger \& Bruch, 2014; Kipfelsberger et al., 2016). Additionally, in Fast Food Industry (FFI), if the administration wants to promote the organizational health $(\mathrm{OH})$ they must be deliberation about employee empowerment, then they could be better performed. In this way, they can more focus our work; provide better services, convenient behaviour \& attitude with customers and enthusiasm of time sacrifices. Finally, Fast Food Industry (FFI) the Employee Empowerment (EE) to do more influence on organization health $(\mathrm{OH})$ because Employees directly engaged with customers.

\subsection{Limitations}

Present research study has summarized on a single zone (Pakistan) due to first-hand data collection. Therefore, we have unable to access the data from multiple zones while behind the point for further studies. Finally, entire research study leaves appropriate knowledge for managers of Pakistani FFI because the managers construct imperative rule on organizational health. Consequently, the managers of FFI should provide suitable empowerment to our employees because employees of FFI directly engage with costumers. Therefore, employees of FFI can create customer satisfaction, customer loyalty, customer retentions, provide perceived service quality which these enhanced the quality of organizational health with our better services, right attitude and behaviour. Thus, the empowerment builds up the feeling like as a personal business, so they work with full dedications. Besides, when they have very serious with our profession and those working on a single agenda, then operational risk ultimately minimized. 


\section{Acknowledgments}

The authors would like to thank the anonymous referees very much for their valuable comments and suggestions. This work would not have been possible without their support. We also thank all those who contributed in diverse ways in making the work complete.

\section{Conflicts of Interest}

The authors declare no conflict of interest.

\section{References}

Åkerlund, H. (2004). Fading customer relationships: Svenska handelshögskolan.

Aktar, S., Sachu, M. K., \& Ali, M. E. (2012). The impact of rewards on employee performance in commercial banks of Bangladesh: An empirical study. IOSR Journal of Business and Management, 6(2), 9-15. https://doi.org/10.9790/487X-0620915

Alamgir, M., \& Shamsuddoha, M. (2004). Service quality dimensions: A conceptual analysis. The Chittagong University Journal of Business Administration, pp. 19.

Archakova, A. (2013). Service quality and Customer satisfaction. Case study: Company X.

Ashraf, T., Sajjad, W., Ridwan, M., Ahmed, D., \& Nazeer, H. (2013). Determinants of consumer complaining behavior: a study of Pakistan. International Journal of Learning \& Development, 3(6), 121-139. https://doi.org/10.5296/ijld.v3i6.6209

Baloglu, S. (2002). Dimensions of customer loyalty: Separating friends from well wishers. Cornell Hotel and Restaurant Administration Quarterly, 43(1), 47-59.

https://doi.org/10.1016/S0010-8804(02)80008-8

Baron, R. M., \& Kenny, D. A. (1986). The moderator-mediator variable distinction in social psychological research: Conceptual, strategic, and statistical considerations. Journal of personality and social psychology, 51(6), 1173. https://doi.org/10.1037/0022-3514.51.6.1173

Behremen, C., \& Doğdubay, M. (2015). YIYECEK VE İÇECEK İŞLETMELERINNDE PSIKONÖROBIYYOKIMYA YAKLAŞIMI1. Balıkesir Üniversitesi Sosyal Bilimler Enstitüsü Dergisi, 18(34), 23-49. https://doi.org/10.31795/baunsobed.645368

Bobâlcă, C. (2013). STUDY OF CUSTOMERS'LOYALTY: DIMENSIONS AND FACETS. Management \& Marketing-Craiova, 1, 104-114.

Bruhn, J. G. (2001). Trust and the Health of Organizations: Springer Science \& Business Media. https://doi.org/10.1007/978-1-4615-0739-0

Busara, G. C. (2016). Impact of Employees Empowerment on Organization Performance: A Case Study of Government Procurement Service Agency. The Open University of Tanzania.

Cartwright, S., \& Cooper, C. L. (2014). Towards organizational health: Stress, positive organizational behavior, and employee well-being Bridging occupational, organizational and public health (pp. 29-42), Springer. https://doi.org/10.1007/978-94-007-5640-3_3 
Comrey, A., \& Lee, H. (1992). Interpretation and application of factor analytic results. Comrey AL, Lee HB. A first course in factor analysis, pp. 2.

Daft, R. L. (2001). Essentials of organization theory and design: South Western Educational Publishing.

De Haan, E., Verhoef, P. C., \& Wiesel, T. (2015). The predictive ability of different customer feedback metrics for retention. International Journal of Research in Marketing, 32(2), 195-206. https://doi.org/10.1016/j.ijresmar.2015.02.004

Doane, D. P., \& Seward, L. E. (2011). Measuring skewness: a forgotten statistic? Journal of statistics education, 19(2). https://doi.org/10.1080/10691898.2011.11889611

Eliwa, R. A. (2006). Study of Customer Loyalty and the Image of the Fine Dining Restaurant. Oklahoma State University.

Elnaga, A. A., \& Imran, A. (2014). The impact of employee empowerment on job satisfaction: theoretical study. American Journal of Research Communication, 2(1), 13-26.

GanjiNia, H., Gilaninia, S., \& Sharami, R. P. M. (2013). Overview of employees empowerment in organizations. Oman Chapter of Arabian Journal of Business and Management Review, 34(983), 1-6. https://doi.org/10.12816/0002369

Grandey, A. A. (2000). Emotional regulation in the workplace: A new way to conceptualize emotional labor. Journal of occupational health psychology, 5(1), 95.

https://doi.org/10.1037/1076-8998.5.1.95

Grandey, A. A., \& Diamond, J. A. (2010). Interactions with the public: Bridging job design and emotional labor perspectives. Journal of Organizational Behavior, 31(2/3), 338-350. https://doi.org/10.1002/job.637

Grant, A. M. (2007). Relational job design and the motivation to make a prosocial difference. Academy of management review, 32(2), 393-417. https://doi.org/10.5465/amr.2007.24351328

Hanaysha, J. (2016). Testing the effects of employee empowerment, teamwork, and employee training on employee productivity in higher education sector. International Journal of Learning and Development, 6(1), 164-178.

Hancer, M., \& George, R. T. (2003a). Job satisfaction of restaurant employees: An empirical investigation using the Minnesota Satisfaction Questionnaire. Journal of Hospitality \& Tourism Research, 27(1), 85-100. https://doi.org/10.1177/1096348002238882

Hancer, M., \& George, R. T. (2003b). Psychological empowerment of non-supervisory employees working in full-service restaurants. International Journal of Hospitality Management, 22(1), 3-16. https://doi.org/10.1016/S0278-4319(02)00032-4

Horst, P. (1953). Correcting the Kuder-Richardson reliability for dispersion of item difficulties. Psychological Bulletin, 50(5), 371. https://doi.org/10.1037/h0062012

Hunjra, A. I., Ul Haq, N., Akbar, S. W., \& Yousaf, M. (2011). Impact of employee 
empowerment on job satisfaction: An empirical analysis of Pakistani service industry. Interdisciplinary Journal of Contemporary Research in Business, 2(11), 680.

Jacoby, J., \& Kyner, D. B. (1973). Brand loyalty vs. repeat purchasing behavior. Journal of Marketing research, 10(1), 1-9. https://doi.org/10.1177/002224377301000101

Jacquiline, F. (2014). Employee empowerment and job satisfaction. Researchjournali's journal of human resource, 2(2), 1-12.

Jones, S., Mason, K., \& Benefield, M. (2011). Collaborative Pedagogical Research on Customer Perceptions of Service Quality in the Fast Food Industry. Paper presented at the Marketing Management Association 2011 Fall Educators' Conference Proceedings.

Kele, A. T. B. A., Mohsin, A., \& Lengler, J. (2017). How willing/unwilling are luxury hotels' staff to be empowered? A case of East Malaysia. Tourism management perspectives, 22, 44-53. https://doi.org/10.1016/j.tmp.2017.01.006

Khadka, K., \& Maharjan, S. (2017). Customer satisfaction and customer loyalty. Centria University of Applied Sciences, Business Management.

Khan, S. (2013). Determinants of customer retention in hotel industry. Journal of Applied Economics and Business, Journal of Applied Economics and Business, 1(3), 42-64.

Kipfelsberger, P., \& Bruch, H. (2014). How customer contact energizes organizations: The vivid proof of making a difference. Paper presented at the Academy of Management Proceedings. https://doi.org/10.5465/ambpp.2014.128

Kipfelsberger, P., Herhausen, D., \& Bruch, H. (2016). How and when customer feedback influences organizational health. Journal of Managerial Psychology.

https://doi.org/10.1108/JMP-09-2014-0262

Korda, A. P., \& Snoj, B. (2010). Development, validity and reliability of perceived service quality in retail banking and its relationship with perceived value and customer satisfaction. Managing Global Transitions, 8(2), 187.

Lendoiro, E., Quintela, Ó., de Castro, A., Cruz, A., López-Rivadulla, M., \& Concheiro, M. (2012). Target screening and confirmation of 35 licit and illicit drugs and metabolites in hair by LC-MSMS. Forensic science international, 217(1-3), 207-215.

https://doi.org/10.1016/j.forsciint.2011.11.006

MacIntosh, R., MacLean, D., \& Burns, H. (2007). Health in organization: Towards a processbased view. Journal of Management Studies, 44(2), 206-221.

https://doi.org/10.1111/j.1467-6486.2007.00685.x

Makinda, R. N., \& Kwasira, J. (2014). An Assessment of Employee Empowerment on Organizational Performance, A Survey of Selected Banks in Nakuru Town. International Journal of Science and Research, 3(10), 1915-1919.

Markey, R., Reichheld, F., \& Dullweber, A. (2009). Closing the customer feedback loop. Harvard Business Review, 87(12), 43-47. 
Maslach, C. (1978). The client role in staff burn-out. Journal of social issues, 34(4), 111-124. https://doi.org/10.1111/j.1540-4560.1978.tb00778.x

Mattila, A. S. (2001). Emotional bonding and restaurant loyalty. Cornell Hotel and Restaurant Administration Quarterly, 42(6), 73-79.

https://doi.org/10.1016/S0010-8804(01)81012-0

Menges, A., \& Ahlquist, S. (2011). Computational design thinking: computation design thinking: John Wiley \& Sons.

Mets, T. (2002). Learning-based strategic development framework: implementation in Estonian company. Management of Organizations: Systematic Research, 23, 83-93.

Morgan, N. A., Anderson, E. W., \& Mittal, V. (2005). Understanding firms' customer satisfaction information usage. Journal of marketing, 69(3), 131-151.

https://doi.org/10.1509/jmkg.69.3.131.66359

Musselwhite, C. (2007). Motivation= Empowerment. Retrieved March, 14.

Newell, S. (1995). The healthy organization: Fairness, ethics and effective management: Routledge.

Nobahar, M., \& Tamadon, M. R. (2016). Barriers to and facilitators of care for hemodialysis patients; a qualitative study. Journal of renal injury prevention, 5(1), 39.

https://doi.org/10.15171/jrip.2016.09

Oliver, R. L. (1997). Loyalty and profit: Long-term effects of satisfaction.

Oliver, R. L., Rust, R. T., \& Varki, S. (1997). Customer delight: foundations, findings, and managerial insight. Journal of retailing, 73(3), 311.

https://doi.org/10.1016/S0022-4359(97)90021-X

Ozcelik, A. O., Akan, L. S., \& Surucuoglu, M. (2007). An evaluation of fast-food preferences according to gender. Humanity \& Social Sciences Journal, 2(1), 43-50.

Parasuraman, A., Berry, L. L., \& Zeithaml, V. A. (1993). More on improving service quality measurement. Journal of retailing, 69(1), 140-147.

https://doi.org/10.1016/S0022-4359(05)80007-7

Parasuraman, A., Zeithaml, V. A., \& Berry, L. L. (1988). Servqual: A multiple-item scale for measuring consumer perc. Journal of retailing, 64(1), 12.

Pearson, R. H., \& Mundform, D. J. (2010). Recommended sample size for conducting exploratory factor analysis on dichotomous data. Journal of Modern Applied Statistical Methods, 9(2), 5. https://doi.org/10.22237/jmasm/1288584240

Quick, J. C., Macik-Frey, M., \& Cooper, C. L. (2007). Managerial dimensions of organizational health: The healthy leader at work. Journal of Management Studies, 44(2), 189-205. https://doi.org/10.1111/j.1467-6486.2007.00684.x

Ramseook-Munhurrun, P. (2012). Perceived service quality in restaurant services: Evidence 
from Mauritius. International journal of management and marketing research, 5(3), 1-14.

Sabir, R. I., Irfan, M., Akhtar, N., Pervez, M. A., \& Ur Rehman, A. (2014). Customer satisfaction in the restaurant industry; examining the model in local industry perspective. Journal of Asian Business Strategy, 4(1), 18.

Scarff, L.-J. (2017). Developing Strategies for Customer Retention. A Case Study on an Irish Car Dealership. Dublin, National College of Ireland.

Schuckert, M., Liang, S., Law, R., \& Sun, W. (2019). How do domestic and international high-end hotel brands receive and manage customer feedback? International Journal of Hospitality Management, 77, 528-537. https://doi.org/10.1016/j.ijhm.2018.08.017

Singh, V., \& Sharma, S. K. (2016). Analyzing the moderating effects of respondent type and experience on the fuel efficiency improvement in air transport using structural equation modeling. European Transport Research Review, 8(2), 12.

https://doi.org/10.1007/s12544-016-0199-3

Suchánek, P., \& Králová, M. (2015). Effect of customer satisfaction on company performance. Acta Universitatis Agriculturae et Silviculturae Mendelianae Brunensis, 63(3), 1013-1021. https://doi.org/10.11118/actaun201563031013

Syaqirah, Z. N., \& Faizurrahman, Z. P. (2014). Managing customer retention of hotel industry in Malaysia. Procedia-Social and Behavioral Sciences, 130, 379-389.

https://doi.org/10.1016/j.sbspro.2014.04.045

Sydänmaanlakka, P. (2002). An intelligent organization: Integrating performance, competence and knowledge management: Capstone.

Tetrick, L. E. (2002). Individual and organizational health. Historical and current perspectives on stress and health, 2, 117-141.

https://doi.org/10.1016/S1479-3555(02)02003-6

Timothy, A. T., \& Abubakar, H. S. (2013). Impact of Employee Empowerment on Service Quality-An Empirical Analysis of the Nigerian Banking Industry. British Journal of Marketing Studies, 1(4), 32-40.

Torokoff, M. (2006). The Importance of Feedback in the Organisation's Development Process. Eesti Majandusteaduse Seltsi I aastakonverents, 20, 22.

Torokoff, M., \& Mets, T. (2005). The learning organisation and learning in the organisation: the concept for improving the labour quality in a school. Management of Organizations: Systematic Research, 35, 203-216.

Türk, K. (2001). Personali juhtimine: Tartu Ülikooli Kirjastus.

Van Jaarsveld, D. D., Walker, D. D., \& Skarlicki, D. P. (2010). The role of job demands and emotional exhaustion in the relationship between customer and employee incivility. Journal of Management, 36(6), 1486-1504. https://doi.org/10.1177/0149206310368998 


\section{Macrothink}

Business and Economic Research

ISSN 2162-4860 2020, Vol. 10, No. 3

Wadhwa, D. S., \& Verghese, M. (2015). Impact of employee empowerment on job satisfaction and organizational commitment: An empirical investigation with special reference to selected cement industry in Chhattisgarh. International Journal in Management and Social Science, 3(3), 280-286.

Wells, C. S., \& Wollack, J. A. (2003). An instructor's guide to understanding test reliability. Testing \& Evaluation Services. University of Wisconsin.

Williams, C. M., Nathan, N., Delaney, T., Yoong, S. L., Wiggers, J., Preece, S., . . Smith, K. (2015). CAFÉ: a multicomponent audit and feedback intervention to improve implementation of healthy food policy in primary school canteens: protocol of a randomised controlled trial. BMJ open, 5(6), e006969. https://doi.org/10.1136/bmjopen-2014-006969

Wilson, M. G., Dejoy, D. M., Vandenberg, R. J., Richardson, H. A., \& Mcgrath, A. L. (2004). Work characteristics and employee health and well-being: Test of a model of healthy work organization. Journal of occupational and organizational psychology, 77(4), 565-588.

https://doi.org/10.1348/0963179042596522

Wirtz, J., Tambyah, S. K., \& Mattila, A. S. (2010). Organizational learning from customer feedback received by service employees. Journal of Service Management.

https://doi.org/10.1108/09564231011050814

Woodman, R., \& Pasmore, W. (2002). The heart of it all: Group-and team-based interventions in organization development. Organization development: A data-driven approach to organizational change, pp. 164-176.

Zwell, M. (2000). Creating a culture of competence: Wiley.

\section{Copyright Disclaimer}

Copyright for this article is retained by the author(s), with first publication rights granted to the journal.

This is an open-access article distributed under the terms and conditions of the Creative Commons Attribution license (http://creativecommons.org/licenses/by/4.0/). 